Коломієць. - Черкаси, 2009. - 298 с. 5. Про Основні засади розвитку інформаційного суспільства в Україні на 2007-2015 роки [Електронний ресурс]: закон України [затверджено Верховною Радою України від 9 січня 2007 року № 537-V]. - Режим доступу : http://zakon4.rada.gov.ua/laws/show/537-16.

УДК 37.091.2:221.895

Ольга Новак

\title{
«АВТОРСЬКА ШКОЛА»: СУТНІСТЬ ПОНЯТТЯ, ОЗНАКИ, РІЗНОВИДИ ТА ОСОБЛИВОСТІ ДІЯЛЬНОСТІ
}

Новак О. М. «Авторська школа»: сутність поняття, ознаки, різновиди та особливості діяльності.

У статті аналізується сучасний підхід до тлумачення поняття «авторська школа» у наукових розробках вітчизняних та зарубіжних учених, а також подано авторське тлумачення поняття «авторська школа». Визначено умови створення, характерні ознаки, різновиди та особливості функціонування авторського навчально-виховного закладу як інноваційної освітньої системи.

Ключові слова: навчально-виховний заклад, інноваційна школа, авторська школа, технологія, авторська технологія, педагогічна система, навчальний процес.

Новак О. М. «Авторская школа»: сущность понятия, признаки, разновидности и особенности деятельности.

В статье анализируется современный подход к толкованию понятия «авторская школа» в научных разработках отечественных и зарубежных ученых, а также подано авторское толкование понятия «авторская школа». Определены условия создания, характерные признаки, разновидности и особенности функционирования авторского учебно-воспитательного заведения как инновационной образовательной системы.

Ключевые слова: учебно-воспитательное заведение, инновационная школа, авторская школа, технология, авторская технология, педагогическая система, учебный процесс.

Novak O. M. «Authorial school»: essence of concept, sign, varieties and features of activity.

In the article the modern approach to interpretation of concept «authorial school» in scientific developments of Ukrainian and foreign scientists is analyzed. Authorial interpretation of concept «authorial school» is given. The terms of creation, characteristic signs, varieties and features of functioning of authorial educational-educator establishment as an innovative educational system are defined.

Key words: educational-educator establishment, innovative school, authorial school, technologies, authorial technology, pedagogical system, educational process.

Створення інноваційних навчально-виховних закладів освіти є пріоритетними напрямами державної політики України в галузі освіти, про що наголошується у Національній стратегії розвитку освіти в Україні на період до 2021 року. Тому, наявність нетрадиційних за типом освітніх закладів- ліцеїв, гімназій, коледжів, колегіумів, авторських шкіл - в освітньому просторі України є водночас: ознакою часу; відгуком на суспільний запит; результатом педагогічного пошуку освітян. Поява нових авторських шкіл, аналіз діяльності уже наявних навчальних закладів цього типу 
вдосконалюють освітянську практику, збагачують науково-педагогічний дискурс.

Аналіз науково-педагогічної літератури засвідчив, що проблема авторських шкіл висвітлюються в працях таких вітчизняних та зарубіжних педагогів, як: О. Адаменко, О. Адамський, В. Алфімов, С. Гончаренко, М. Гузик, Н. Дічек, Н. Островерхова, Т. Перекрьостова, Н. Побірченко, О. Попова, М. Поташник, О. Савченко, О. Саранов, Г. Селевко, О. Сухомлинська, Т. Цирліна, Ю. Юрчонок та ін.

Mета статті полягає в з'ясуванні сутності поняття «авторська школа» та аналізу наукових розробок вітчизняних та зарубіжних дослідників до його вивчення. Визначення характерних ознак авторського навчально-виховного закладу.

Теоретичний аналіз і осмислення досліджуваної проблеми потребують розгляду тісно пов'язаних феноменів, як «школа» та «авторська школа».

С. Гончаренко зазначає, що школа - це «навчально-виховний заклад для навчання, освіти і виховання дітей, молоді та дорослих. Школа - явище історичне, завдання і зміст іiі змінювалися зі зміною суспільно-економічного ладу. Школа покликана здійснювати розумове, трудове, моральне, фізичне й естетичне виховання учнів, прилучаючи підростаюче покоління до духовної культури та матеріального виробництва, озброюючи його необхідними знаннями і способами діяльності [2, c. 364]».

В «Енциклопедії освіти» зазначається, що «школа - це соціальний інститут, покликаний задовольнити освітні потреби особистості, суспільства, держави. Провідною функцією іiі $\epsilon$ соціалізація вихованців, збереження та відтворення соціокультурного досвіду людства [6, с. 1007]».

У сучасній науково-педагогічній літературі $\epsilon$ чимало визначень поняття «авторська школа», які характеризують цей феномен з різних сторін і водночас свідчать про відсутність єдиного підходу в його дослідженні.

У педагогічному словнику під редакцією С. Гончаренко дано наступне визначення: «авторська школа- оригінальна загальнопедагогічна, дидактична, методична чи виховна система, опрацьована з урахуванням надбань психології, педагогіки, вікової фізіології та інших наук, вітчизняного й зарубіжного педагогічного досвіду, яка реалізується під керівництвом чи за участю їі автора (авторів) принаймні в одному навчально-виховному закладі (наприклад, школа В. Сухомлинського, школа М. Гузика та ін.). Авторська школа є одним із типів експериментального майданчика $[2$, c. 14$] »$.

В «Енциклопедії освіти» зазначається, що «авторська школа - це навчальновиховний заклад, у якому реалізується нова педагогічна система, розроблена конкретним педагогом чи творчим педагогічним колективом. Авторські школи виникають переважно як відповідь на гострі потреби вдосконалення освітньої практики, соціальної затребуваності певних ідей щодо навчання, виховання і розвитку дітей $[6$, с. 8$] »$.

Ряд науковців (Н. Островерхова, Н. Побірченко, Ю. Юрчонок та ін.) розглядають авторську школу як навчальний заклад, побудований на гуманістичних засадах. Так, Н. Островерхова вважає, що авторський заклад освіти в системі інших навчальних закладів виступає як форма реалізації соціальних перетворень та суспільних відносин. Він покликаний забезпечити сприятливі умови для реалізації і самореалізації потенціальних можливостей кожного учня, його інтелектуального, морального, емоційного та фізичного розвитку; формування світогляду, гуманних відносин на основі загальнолюдських цінностей [9, с. 26]. За визначенням вітчизняної дослідниці Н. Побірченко, «авторська школа - це гуманістичний навчально-виховний заклад, ідея створення якого належить педагогу-творцю, який розробив і поклав в основу його 
діяльності власну концепцію розвитку школи, основою якої є тріада дитина-вчительбатьки, що забезпечує ефективне функціонування і стабільні позитивні результати $[13$, с. 36]». Ю. Юрчонок, розглядає авторську школу як гуманістичну, експериментальну навчально-виховну установу, в якій реалізовується оригінальна цілісна інноваційна педагогічна система, суб'єктами діяльності якої стають педагогічний колектив, учні, батьки в тісній взаємодії [19, с. 9].

Такі науковці як В. Алфімова, Н. Дічек, Н. Островерхова, Н. Побірченко, Ю. Юрчонок та інші вказують, що авторські школи побудовано на оригінальній концепції автора, і розглядають авторську школу з позиції педагогічної системи, яка відображає філософські, соціологічні та психолого-педагогічні ідеї автора. Так, поняття «авторська школа» дослідниця Н. Дічек тлумачить як «явище новаторської або інноваційної навчально-виховної практики, що теоретично спирається на оригінальну педагогічну концепцію, розроблену й успішно запроваджену іiі автором, тобто педагогом-новатором [5, с. 8]». Дослідник В. Алфімов розглядає авторську школу 3 позиції унікальної соціально-педагогічної системи, яка відображає філософські, соціологічні та психолого-педагогічні ідеї автора (авторів) [1, с. 19]. В. Алфімов переконаний, що авторська школа завжди унікальна. Ця школа $\epsilon$ результатом багаторічної особливої педагогічної практики, відтворити яку повною мірою неможливо. Важливим критерієм авторської школи $є$ гуманістичне спрямування педагогічної системи.

У визначеннях поняття «авторська школа» науковці М. Гузик, О. Попова, Г. Селевко та інші акцентують увагу на використанні технологій у діяльності цих навчальних закладів. Так, на думку директора авторської школи-комплексу № 3 м. Южне, Одеської області М. Гузика, «авторська школа $є$ повністю інноваційним освітнім закладом: мета, завдання, зміст та технологія освіти, що реалізуються в ньому, відрізняються від уже відомих зразків принципово новими підходами, рішеннями та високою ефективністю [3, с. 49]». Російський дослідник Г. Селевко зазначає, що «авторською (інноваційною) школою називається навчально-виховний заклад, діяльність якого побудована на оригінальних (авторських) ідеях і технологіях і $\epsilon$ новою освітньою практикою (або взагалі, або для даних умов) [15, с. 63]». О. Попова пропонує таке визначення: «авторська школа - це навчально-виховний заклад, який побудований на оригінальних (авторських) ідеях та технологіях і має в наявності результати, котрі визначають реальність та ефективність його функціонування [14, c. 15]».

Отже, «авторська школа» на нашу думку $є$ інноваційний високоефективний навчально-виховний заклад, в якому апробується оригінальна авторська технологія, ідея створення якої належить педагогу-творцю або творчому колективу, та забезпечується ефективне функціонування цього закладу, підвищується результативність навчально-виховного процесу.

Таким чином, аналіз поняття «авторська школа» показав, що не має єдиного підходу до його визначення, а процес остаточного формування досліджуваного феномену ще не завершився. Вчені продовжують наукові дискусії, які доводять, що еволюція авторських шкіл продовжується.

Зазначимо, що авторська школа $\epsilon$ складною розгалуженою педагогічною системою або, іншими словами, полісистемою, яка складається 3 цілої низки обов'язкових підсистем відповідних до конкретних завдань розвитку особистості учня: навчальної, трудової, художньо-естетичної, духовно-релігійної, спортивної, наукової.

Школа як живий організм, здатний до самоорганізації, саморефлекції, розвиває, 
підтримує цілі, які тісно пов'язані 3 ідеалами й цінностями кожної дитини. Опікуючись особистісними цілями своїх вихованців та їх батьків, школа нерідко вступає в протиріччя з офіційними установками, намагається вчасно реагувати як на виклики часу, так і на потреби особистості. На цьому тлі виникають авторські школи 3 носіями реформаційних ідей щодо мети, шляхів і засобів навчання й виховання дітей, що спираються на педагогічну рефлексію [16].

Однією $з$ важливих умов створення і функціонування авторського навчальновиховного закладу $\epsilon$ врахування особливостей зовнішнього (макро- i мікро-) середовища, зокрема, рівня політичного, соціально-економічного та культурноосвітнього розвитку країни. Макросередовище $є$ вирішальним фактором у визначенні соціального статусу авторського навчального закладу.

Створення і функціонування авторського закладу освіти обумовлюється не лише специфікою зовнішнього макросередовища, а й коригується особливостями (регіону, району, мікрорайону, міста, села). Вплив зовнішнього мікросередовища більшою мірою проявляється у визначенні профілю навчально-виховного закладу, пріоритетного аспекту його діяльності, змісту освіти і виховання учнів. Разом 3 тим, не слід абсолютизувати вплив зовнішнього середовища на авторський заклад освіти: його сутність і особливості обумовлюються значною мірою внутрішньою природою компонентів, характером їх взаємодії. Такими компонентами є: педагогічний та учнівський колективи, адміністративно-управлінський i допоміжний персонал, навчально-матеріальна база. Творчий потенціал педагогічного колективу, скоординованість дій основних учасників навчально-виховного процесу, згуртованість на основі бажань і устремлінь творити нове, впроваджувати педагогічні інновації, досягати високих результатів педагогічної праці обумовлюють формування відмінних від стандартних взаємовідносин у підсистемах: «учитель- учень», «учитель - батьки», «учитель - адміністрація», «учитель - учитель». Характер взаємодії між цими підсистемами трансформується через специфічні мету, зміст, принципи, форми, методи, засоби та технології навчання, що є визначальною ознакою авторського навчально-виховного закладу [8].

Авторські школи виникають на основі оригінальної концепції освіти. Розробка концепції авторської школи вимагає від керівника володіння аналітико-синтетичним мисленням, яке передбачає: аналіз та оцінку доцільності трансформації нових філософських, соціологічних, психолого-педагогічних ідей i теорій в діяльність авторського закладу освіти; аналіз та оцінку оптимальності соціально-економічних та психолого-педагогічних умов функціонування авторського закладу освіти; аналіз та оцінку правильності визначення мети і завдань, пріоритетного аспекту діяльності авторського закладу освіти; аналіз та оцінку ефективності теоретичних засад організації і змісту навчання і виховання учнів авторського закладу освіти; аналіз доцільності впровадження програмно-цільового методу управління діяльністю авторського закладу освіти, який передбачає близьку і далеку перспективи його розвитку.

Як правило, авторські школи створюються на базі існуючих навчальних закладів, та, на думку дослідниці Н. Побірченко, виконують низку важливих функцій: поширення гуманістичних цінностей i пріоритетів особистісно орієнтованої педагогіки; забезпеченя більш високого, порівняно з традиційним, рівня виховання, що визначається взаємовідносинами співробітництва і партнерства всіх суб'єктів навчально-виховного процесу; змістове нарощування i реальне опредмечування обраних домінантних цінностей в педагогічному процесі; спрямованість на творчий пошук і професійне зростання, а також постійне стимулювання механізму, що сприяє 
трансформації існуючої педагогічної практики і розвитку інноваційного мислення, виконуючи при цьому роль «ключової школи»; опредмечення вже самим фактом свого існування нового футурологічного простору, який випереджає педагогічні традиції сучасності й виводить педагогів зі школи в інші часові поля, створюючи основи для формування «школи майбутнього» [13, с. 34].

Діяльність авторської школи здійснюється на демократичних та гуманістичних засадах, упровадженні різноманітних систем навчання і виховання з урахуванням потенціальних можливостей учнів, їх творчих здібностей, нахилів та інтересів; у такій школі зусилля спрямовані на формування вільної особистості, яка вміє самостійно думати та діяти, громадянина-гуманіста, здатного робити обгрунтований вибір у різноманітних навчальних та життєвих ситуаціях.

Тому ми вважаємо, що в авторських школах йде постійна науково-дослідницька робота, що передбачає наявність: теоретичної концепції, яка пояснює вибір ключових моментів освітньої системи, що діагностуються і за станом яких можна прогнозувати кінцеві результати та внесок у них основних підсистем; авторської технології, яка поетапно реалізує теоретичну концепцію; групи вчителів, вихователів, учнів, які беруть участь у комплексному дослідженні; організації проведення дослідження, обговорення його результатів, узагальнення накопиченого досвіду.

Т. Цирліна виділяє ряд компонентів, сукупність яких забезпечує діяльність авторської школи: наявність автора, лідера педагогічного колективу; сформульована автором концепція школи; пошуковий характер діяльності, здійснення експерименту; синтез світоглядної концепції i інноваційних технологій; творчий порівняно 3 масовою школою характер життєдіяльності; включення учнів, що вчаться, та їх батьків у процес реалізації авторської концепції; стійкість і стабільність результатів $[18$, c. 38$]$.

На думку Ю. Юрчонок, основними ознаками авторського закладу освіти є: наявність автора-лідера, здатного до запровадження та поширення інноваційних ідей; створення оригінальної концепції авторської школи; інноваційний та експериментальний характер діяльності школи; наявність колективу педагогіводнодумців; створення необхідних умов для самореалізації особистості кожного учня; оригінальний концептуальний підхід до організації навчально-виховного процесу; наявність матеріальної бази, необхідної для упровадження нововведень; залучення всіх суб'єктів (учителів, учнів, батьків) до процесу реалізації авторської концепції; стабільні, стійкі та позитивні результати тощо [19, с. 10].

У контексті нашого дослідження важливою $є$ позиція Т. Перекрьостової, яка виділяє наступні характерні ознаки авторської школи: вона унікальна, оскільки нею рухає внутрішня сила творчості автора i його однодумців; у ній формується специфічна педагогічна культура як динамічна система педагогічних цінностей, професійної поведінки, педагогічної позиції вчителя щодо дітей; у такій школі створюється особлива моральна атмосфера, яка значною мірою визначається педагогічним кредо іiі творця-автора, а його особисті цінності в процесі спільної діяльності стають цінностями всіх суб'єктів школи; для неї характерний процес саморозвитку, самоорганізованості, рушійною силою якого виступає експериментальна інноваційна педагогічна діяльність [12, с. 135].

Отже, основними ознаками авторської школи, на нашу думку є: наявність автора; створення оригінальної концепції авторської школи; пошуковий характер діяльності, здійснення експерименту; синтез світоглядної концепції і авторської технології; залучення всіх суб'єктів (учителів, учнів, батьків) до процесу реалізації авторської концепції; наявність колективу педагогів-однодумців; стійкість і стабільність 
результатів порівняно з масовою школою.

Зазначимо, що сучасні дослідники по-різному підходять до розподілу авторських шкіл на типи та групи. Так, російські вчені А. Каспржак та М. Левіт, одні з перших зробили розподіл авторських шкіл за типами: школи, що претендують на звання нових начальних закладів; установи, що займаються пошуком шляхів інтеграції 3 педагогічними школами Заходу; школи, що виникли в епоху боротьби з авторитарною системою радянської педагогіки; відомчі школи; експериментальні школи [18].

Російський дослідник I. Трухін авторські школи поділяє на п'ять груп: школи, що втілюють ідеї «вільного виховання»; школи, які реалізовують ідеї «розвивального виховання»; спеціалізовані школи, що мають будь-який професійний нахил або призначені для певної категорії дітей; школи, в яких головним нововведенням $\epsilon$ навчання дітей за індивідуальними програмами; школи синтезу всього, що уявляється новим і корисним [17].

На основі узагальнення найістотніших ознак авторської школи, історичних i суспільних особливостей їх функціонування Т. Цирліна репрезентувала свою розгалуджену типологізацію, групуючи їх за такими ознаками: за типом закладу державні, недержавні, світські, конфесійні, а також за статусом соціуму - закриті, відкриті, «школи без стін»; за цілеціннісною спрямованістю - за пріоритетними видами діяльності (пізнання, дії, клубної структури, спрямування на забезпечення здоров’я та фізичної досконалості, комбінований варіант), за загальною орієнтацією (космополітичні, національно-демократичні, особистісно орієнтовані), за типом управління: авторитарні, демократичні; за домінуючою функцією (загальноосвітні, виховні, соціально-реабілітаційні); за особливостями здійснення пошуків - за ступенем новизни (адаптаційні, комбіновані, радикальні), за рівнем поширення (одиничні, локальні, національні, універсальні), за масштабом реального втілення (авторська концепція, авторський проект, школа як одиничне явище, школа-модель, школа-напрям, школа як основа нової парадигми) [18].

Аналіз зарубіжної та відчизняної літератури засвідчує, що єдиної типологізації авторських шкіл немає.

Вивчення вітчизняної та зарубіжної літератури 3 даної проблеми дозволяє зробити висновок, що перед кожним авторським навчально-виховним закладом ставиться своя, специфічна, оригінальна авторська мета. Відповідно до педагогічної ідеї та мети діяльності авторської школи розробляється і реалізується оригінальна система навчання і виховання учнів, що забезпечує досягнення поставленої мети, створюються відповідні умови для реалізації навчально-виховних завдань.

В авторській школі зміст освіти має свою специфіку і обумовлюється: метою, завданнями та девізом діяльності школи; специфікою пріоритетного аспекту діяльності школи, який для неї є проблемним і відповідає меті та завданням школи; різновидом авторської школи, ступенем та профілем навчання; рівнем творчого потенціалу педагогічного і учнівського колективів; рівнем навчально-матеріального забезпечення. Авторські школи мають свої специфічні ознаки, різновиди та особливості діяльності та $є$ інноваційними навчально-виховними закладами, які функціонують не лише в Україні, а й за їі межами.

Отже, можемо зробити висновок, що авторська школа сьогодні стає одним 3 провідних інноваційних закладів освіти в яких апробовуються авторські технології $\mathrm{i}$ методики. Сучасні авторські школи сприяють забезпеченню сприятливих умов для реалізації i самореалізації потенціальних можливостей кожного учня, його інтелектуального, морального, емоційного та фізичного розвитку, формування світогляду, гуманних відносин на основі загальнолюдських цінностей. 


\section{Література}

1. Алфимов В. М. Авторская школа : критерии и показатели / В. М. Алфимов // Директор школи. Україна. - 2002. - № 3. - С. 19-21. 2. Гончаренко С. У. Український педагогічний словник / С. У. Гончаренко. - К. : Либідь, 1997. - 376 с. 3. Гузик М. П. Школа, якою керує Бог...: (до концепції авторської експериментальної школи-комплексу) / М. П. Гузик // Директор шк., ліцею, гімназії. - 2000. - № 1. С. 48-54. 4. Дичківська І. М. Інноваційні педагогічні технології : [навч. посіб.] / I. М. Дичківська. - К. : Академвидав, 2004. - 352 с. 5. Дічек Н. П. До питання теоретичного узагальнення феномену педагогічного новаторства (ретроспективний вимір) / Н.П. Дічек // Історико-педагогічний альманах. - 2009. - № 2. - С. 4-13. 6. Енциклопедія освіти / за ред. В. Г. Кременя. - К. : Юрінком Інтер, 2008. - 1040 с. 7. Національна стратегія розвитку освіти в Україні на період до 2021 року [Електронний pecypc].- Режим доступу: http://www.president.gov.ua/documents/ 15828.html 8. Осторверхова Н. М. Парадигми управління авторськими закладами освіти / Н. М. Остороверхова. - К. : Глобус, 1998. - 276 с. 9. Осторверхова Н. М. Чи можна керувати «Школою свободи»? / Н. М. Остороверхова // Директор шк., ліцею, гімназії. - 2000. - № 1. - С. 26-33. 10. Педагогічні технології. Досвід. Практика : довідник / за ред. П. І. Матвієнко. - Полтава : [б.в.], 1999. - 375 с. 11. Педагогічні технології : теорія та практика : [навч.-метод. посіб.]/ К. О. Вовк [та ін.] ; ред. М. В. Гриньова. - Полтава : ACMI, 2006. - 230 с. 12. Перекрестова Т. С. Методологические основы исследования и проектирования авторской школы как инновационной образовательной системы [Электронный ресурс]/ T. С. Перекрестова // Вестник Оренбургского государственного педагогического университета. - 2013. - № 1(5). - Режим доступа: www.vestospu.ru 13. Побірченко Н. С. Змістовий аспект поняття «авторська школа»/ Н. С. Побірченко // Вісник Житомирського державного університету імені Івана Франка. - Житомир, 2007. - Вип. 36. - С. 33-37. 14. Попова О. В. Становлення і розвиток інноваційних педагогічних ідей в Україні у ХХ ст. : [монографія] / О. В. Попова. - Харків : «ОВС», 2001. - 256 с. 15. Селевко Г. К. Педагогические технологии авторских школ / Г. К. Селевко. - М. : НИИ школ. технологий, 2005. - 192 с. 16. Сухомлинська О. В. Авторські педагогічні системи як складова оновлення національної школи / О. В. Сухомлинська // Вісник Житомирського державного університету імені Івана Франка. Житомир, 2007. - № 36. - С. 24-27. 17. Трухин И. А. Очерк педагогического новаторства XX века [Электронный ресурс] / И. А. Трухин // Афинская Академия. - 2008. - 10 окт. Режим доступа: http://www.athens.kiev.ua/academy/novaz01.htm. - Название с экрана. 18. Цырлина Т. В Авторская школа: дефиниции, типологии и тенденции развития [Электронный ресурс] / Т. В. Цырлина // Российско-американский форум образования : электронный журнал. - Vol. : 2, Issue: 1, 2010. - Вып. 1/04 - Режим доступа : www.rusameeduforum.com/ content $/ \mathrm{ru} / \mathrm{?}$ task $=$ art\&article...iid $=6$ 19. Юрчонок Ю. В. «Авторська школа» : до визначення сутності поняття / Ю.В.Юрчонок// Гуманізація навчальновиховного процесу : [зб. наук. праць]. - Слов'янськ, 2009. - Вип. 46 (XLVI). - С. 293-296. 20. Янкович О. І. Освітні технології в історії розвитку вищої педагогічної освіти України : [монографія] / О. І. Янкович. - Тернопіль : Підручники і посібники, 2008. $320 \mathrm{c}$. 